Ewa Jastrzębska

Szkoła Główna Handlowa w Warszawie e-mail: ejastr@sgh.waw.pl

Paulina Legutko-Kobus

Szkoła Główna Handlowa w Warszawie e-mail: plegut@sgh.waw.pl

\title{
EKONOMIA WSPÓŁPRACY - DEFINICJE, KLASYFIKACJE I DOBRE PRAKTYKI
}

\section{Abstract \\ Collaborative Economy - Definitions, Classifications, and Good Practices}

Collaborative economy $(\mathrm{CE})$ is currently a growing trend - responding to the rapid development of ICT. The article presents the CE formulation process - its genesis, definitions and categories. It includes also analysis of Polish good examples of the CE.

Keywords: collaborative economy, sharing economy, ICT, cooperation, open and horizontal management, good practices.

\section{Streszczenie}

Ekonomia współpracy (EW) to nasilający się współcześnie trend - stanowiący odpowiedź na szybki rozwój ICT. Artykuł stanowi próbę charakterystyki EW - jej genezy, definicji i kategoryzacji. Przeanalizowano w nim także dobre praktyki EW w Polsce.

Słowa kluczowe: ekonomia współpracy, ekonomia współdzielenia, ICT, współpraca, otwarte i poziome zarządzanie, dobre praktyki.

\section{Wprowadzenie}

Millenialsi to pokolenie urodzone na przełomie wieków, wychowane w erze cyfrowej, zwane generacją sieci po pierwsze dlatego, że dorastało w epoce gwałtownego upowszechniania narzędzi ICT, które doskonale rozumie, a po drugie, że za pośrednictwem mediów społecznościowych cały czas pozostaje w kontakcie z innymi użytkownikami Internetu, z którego także czerpie wiedzę o świecie. 
Łatwość korzystania z ICT to główny wyznacznik tego pokolenia, które poza tym wymyka się jednoznacznej klasyfikacji. Niektóre badania dowodzą, że jest to pokolenie potrafiące się elastycznie i świadomie adaptować się do zmian, innowacyjne, ceniące prawa jednostki, wolność i swobodę działania, mające zarazem silne poczucie wspólnego dobra i odpowiedzialności obywatelskiej, także świadomość współczesnych globalnych zagrożeń, w tym ekologicznych, wynikających z powszechnego konsumpcjonizmu i marnotrawstwa zasobów [PwC, 2016: 7]. Inne z kolei badania podkreślają, że wbrew powszechnym opiniom, Millenialsi są grupą wiekową, która najczęściej odwiedza biblioteki (co nie jest tak zaskakujące, wynika bowiem z mniejszej zamożności tej grupy, przyzwyczajenia do dzielenia się, w tym wspólną przestrzenią jako miejscem spotkań) [Geiger, 2017]. Równocześnie to młode pokolenie, wchodzące na rynek pracy, jest w największym stopniu dotknięte skutkami kryzysu 2007+, w tym wysokim bezrobociem.

Millenialsi są zatem siłą napędową intensywnie rozwijającego się w ostatnich latach zjawiska zwanego ekonomią współpracy (EW). EW jest nie tylko zgodna z naturą i filozofią życiową Millenialsów (otwartość, ufność, chęć pomocy innym i dzielenia się, aktywność), lecz także odpowiada na ich wysokie oczekiwania (wysoka jakość życia, zdobywanie nowych doświadczeń, dużo lepsze wykorzystanie posiadanych, ograniczonych zasobów). Jak zauważa Tomio Geron [2013], Millenialsi nie kupują gazet, oni chwytają i rozpowszechniają historie za pomocą Facebooka i Twittera, zamiast kupować DVD i CD - pobierają wideo i subskrybują muzykę - jak mówi Jeremiah Owyang [2014a]; dla nich dzielenie się jest nowym sposobem kupowania (sharing is the new buying). Jednak takie zachowania przejmują także inne, starsze grupy pokoleniowe: Y, X, a nawet baby boomers - EW dotyczy w mniejszym lub większym stopniu wszystkich [Conley, 2017]. Bardziej niż zjawiskiem społecznym, EW jest trendem wynikającym z postępu technologicznego - rewolucja cyfrowa, która ukształtowała Millenialsów, przyczyniła się bowiem do narodzin EW.

Mając na względzie powyższe, w niniejszym artykule podjęto tematykę ekonomii współpracy, tego coraz bardziej mainstreamowego trendu, którego fenomen analizowany jest coraz częściej zarówno przez ekonomistów, jak i socjologów. Celem artykułu jest próba charakterystyki EW - w tym genezy, definicji i kategoryzacji tego zjawiska. Artykuł odnosi się także do polskich dobrych przykładów EW. Ze względu na nowatorski charakter analizowanego zjawiska, jako metoda badawcza została zastosowana głównie analiza źródeł internetowych (web research), a także krytyczna analiza literatury przedmiotu.

\section{Ekonomia współpracy — geneza i definicje}

Ekonomia współpracy to nasilający się współcześnie fenomen - nowych i cały czas ewoluujących, złożonych i różnorodnych zjawisk, wzajemnie się napędzających, o znaczącej skali i konsekwencjach. Można EW ujmować wąsko, ale można także doszukiwać się jej w prawie każdym przejawie życia społecznego 
i gospodarczego. Dotyczy ona bowiem różnych dziedzin, sektorów gospodarki, modeli biznesowych oraz stylów życia czy zarządzania.

W latach siedemdziesiątych XX wieku ten nowy trend zaczęto określać jako konsumpcja współdzielona, współkonsumpcja (collaborative consumption) [Stokes et al., 2014: 9]. Od początku XXI wieku, początkowo głównie w Stanach Zjednoczonych, zaczęto używać pojęć: ekonomia wzajemności czy ekonomia rówieśników (peer economy, P2P economy) ${ }^{1}$ oraz ekonomia współdzielenia (shared economy, sharing economy), ze względu na istotne znaczenie współużytkowania i współdzielenia nie w pełni wykorzystywanych zasobów w rozwoju tego nowego trendu, a także z uwagi na sukcesy i popularność czołowych serwisów ekonomii współdzielenia (np. Airbnb czy Uber). Na nowe zjawisko zwracali uwagę w 2006 roku Don Tapscott i Anthony D. Williams [2006], tworząc pojęcie wikinomii (wikinomics), czyli darmowości w sieci, której najlepszym przykładem jest Wikipedia, tworzona bezinteresownie przez internautów. W uznaniu dla tego nowego zjawiska w 2006 roku „Time” przyznał społeczności internetowej tytuł Człowieka Roku [Grossman, 2006]. Z kolei Jeremy Rifkin [2014], analizując globalne trendy, pisał o społeczeństwie zerowych kosztów krańcowych, w którym internet rzeczy (Internet of Things) zapoczątkował zmierzch kapitalizmu, dając początek nowemu systemowi ekonomicznemu - wspólnocie współpracy, bazującej na prawie bezpłatnych dobrach współdzielonych (collaborative commons).

Zamęt definicyjny, powodowany przez funkcjonowanie różnych określeń ${ }^{2}$, oraz dyskusje nad zdefiniowaniem fenomenu nowych zjawisk, doprowadziły do sformułowania w 2009 roku terminu ekonomii współpracy (collaborative economy), który od 2014 roku [Owyang, 2014b] uznaje się za najlepiej oddający różnorodność i złożoność tego trendu [Sokołowski et al., 2016: 13-14].

Wskazuje się na różnice pomiędzy określeniem EW i pozostałymi pojęciami, ale także na elementy wspólne, tj. rozproszone sieci jednostek i społeczności, podobne, wspomniane we wstępie stymulanty rozwoju oraz innowacyjne i efektywne wykorzystanie ukrytego bogactwa dotychczas nie w pełni wykorzystywanych zasobów [Botsman, 2013]. Nadal jednak pojawiają się głosy odmienne - np. że bardziej precyzyjnym określeniem nowych zjawisk jest ekonomia dostępu (access economy), spopularyzowana przez Rifkina [2000], bo ciągle chodzi o transakcje wymiany, w której konsumentom zależy przede wszystkim na obniżce kosztów, a nie na budowaniu relacji z innymi [Eckhardt, Bardhi, 2015], zaś starzy pośrednicy zastępowani są nowymi [Makkonen, 2015]. Mimo tej krytyki, autorki są zdania, że określenie ekonomia współpracy najlepiej oddaje istotę nowego zjawiska, podkreślając, że choć napędza je Internet, to funkcjonuje ono dzięki współpracy użytkowników sieci.

${ }^{1} \mathrm{P} 2 \mathrm{P}$ - sieć komputerowa umożliwiająca komunikację użytkowników na równorzędnych zasadach.

${ }^{2}$ W 2014 r. J. Owyang [2014a] zidentyfikował ich ponad 37. 
Początkowy wzrost popularności EW zawdzięcza [Sokołowski et al., 2016: 13]:

- pierwszym publikacjom z tego zakresu³,

- TED Talks Rachel Botsman (The case for collaborative consumption $2010 \mathrm{r}^{4}$, , The currency of the new economy is trust - 2012 r. ${ }^{5}$ ),

- pierwszym artykułom prasowym opisującym nowe zjawisko w magazynach takich jak „Time”, „The Economist” ${ }^{\prime}$ „,Forbes"8 (2012/2013),

- pierwszym wydarzeniom, zorganizowanym przez społeczność pionierów ekonomii współpracy OuiShare (przede wszystkim OuiShare Summit w Paryżu w 2012 r.),

- powstaniem Crowd Companies - rady korporacji zainteresowanych ekonomią współpracy, założonej przez J. Owyanga (grudzień 2013).

\section{Rachel Botsman}

- gospodarka zbudowana na rozproszonych sieciach połączonych ze soba jednostek i społeczności, zdecydowanie różniących się od scentralizowanych instytucji,

transformująca sposób w jaki można produkować, konsumować, finansować i uczyć się (2013)

- system zdecentralizowanych sieci i rynków, które odblokowują ukrytą wartość nie w pełni wykorzystanych zasobów poprzez dopasowanie potrzebujących do posiadających w sposób omijający tradycyjnych pośredników (2015)

Jeremiah Owyang

- model ekonomiczny, w którym powszechnie dostępne technologie umożliwiają ludziom dostanie tego, czego od siebie nawzajem potrzebuja (2015)

OuiShare

- inicjatywy bazujące na horyzontalnych sieciach i zaangażowaniu społeczności, oparte o energię i zaufanie wspólnot, w opozycji do scentralizowanych instytucji, zacierające granice między producentem a konsumentem, w ramach których interakcje odbywaja się za pośrednictwem sieci internetowych i platform P2P jak również współdzielonych przestrzeni (2016)

Rysunek 1. Wybrane definicje ekonomii współpracy

Źródło: opracowanie własne na podstawie: Botsman, 2013; 2015; Owyang, 2015; The collaborative economy, 2016.

${ }^{3}$ W 2010 r. ukazały się dwie publikacje istotne z punktu widzenia rozwoju całej koncepcji: The Mesh: Why the Future of Business Is Sharing Lisy Gansky (Portfolio Penguin) oraz What's Mine is Yours: The Rise of Collaborative Consumption Rachel Botsman i Roo Rogersa (Harper Collins Publishers).

${ }^{4}$ www.ted.com/talks/rachel_botsman_the_case_for_collaborative_consumption?language $=\mathrm{pl}$ [dostęp: 15.12.2016].

5 www.ted.com/talks/rachel_botsman_the_currency_of_the_new_economy_is_ trust?language $=\mathrm{pl}$ [dostęp: 15.12 .2016$]$.

610 Ideas That Will Change the World (March 17, 2011).

${ }^{7} \mathrm{~Np}$. Wheel-time sharing (March 25, 2012), The rise of the sharing economy oraz All eyes on the sharing economy (March 9, 2013).

${ }^{8}$ Np. Will Ride-Sharing Apps Replace Car Ownership? (July 9, 2012), Airbnb And The Unstoppable Rise Of The Share Economy (January 23, 2013). 
Różnorodność, złożoność i wielowymiarowość EW, a także trwający proces jej kształtowania się sprawiają, że nie jest ona jednoznacznie i precyzyjnie zdefiniowana. Na Rysunku 1 zestawiono wybrane, najczęściej przywoływane, definicje EW. Warto zauważyć, że we wszystkich przytoczonych definicjach podkreśla się, że EW bazuje na sieci (a zatem ICT). I o ile wcześniejsze definicje postrzegały EW przede wszystkim w kontekście rynku, o tyle najnowsza definicja (QuiShare) kładzie większy nacisk na wymiar społeczny tego zjawiska.

Ważną rolę w powstaniu i rozwoju EW odegrała rewolucja technologiczna, której obecnie jesteśmy świadkami, przejawiająca się rozwojem technologii mobilnych i mediów społecznościowych. Powoduje ona zmianę modeli organizacyjnych i dystrybucyjnych - przejście od modelu ,jeden-do-wielu” do modelu „każdy-do-każdego" (peer-to-peer), w którym ludzie mogą bezpośrednio wymieniać się dobrami i usługami, z pominięciem pośredników. Pojedyncze osoby wchodzą z sobą w interakcje, wytwarzając produkty i usługi oraz dystrybuując je, zacierając tym samym granice pomiędzy producentami a odbiorcami. Dzięki wykorzystaniu ICT redukowane są koszty transakcyjne (o czym wspominał Rifkin), wymiana (w tym dóbr, które nie były wcześniej brane pod uwagę) staje się tańsza i łatwiejsza niż kiedykolwiek wcześniej i możliwa na dużo większą skalę, a informacja na temat dóbr, które mogą być przedmiotem wymiany - szerzej dostępna i wiarygodniejsza (dzięki systemom reputacyjnym) [The rise of the sharing economy, 2013]. Przekłada się to zatem nie tylko na fundamentalne zmiany w gospodarce (nowy wymiar wymiany), lecz także na relacje międzyludzkie, w wielu bowiem transakcjach EW to nie pieniądz jest walutą, lecz np. czas wolny czy umiejętności ${ }^{9}$.

Podsumowując prowadzone rozważania i próbując syntetycznie zdefiniować EW, można zatem przyjąć, że istotą EW są rozproszone sieci powiązanych z sobą jednostek i społeczności, czyli współpraca (której fundamentem jest zaufanie), ale stymulowana i wspomagana narzędziami $\mathrm{ICT}^{10}$.

Do głównych cech przedsięwzięcia EW (które nie polega tylko na „uberyzacji”, czyli zastosowaniu geolokacji i płatności online) należy zaliczyć:

- umożliwienie dzięki ICT,

- łączenie rozproszonych sieci osób i aktywów,

- wykorzystywanie marnotrawionego potencjału materialnych i niematerialnych zasobów,

- zachęcanie do interakcji i budowania zaufania,

- wspieranie otwartości, włączenia i wspólnoty [Stokes et al., 2014: 11].

W tym kontekście warto podkreślić, że przedsięwzięcia EW są bardzo często innowacjami społecznymi, czyli nowymi, efektywniejszymi rozwiązaniami,

9 W ramach modelu biznesowego amerykańskich firm SideCar i Lyft oferowana jest ,podwózka przez znajomego", któremu za czas spędzony razem w podróży pasażer rewanżuje się dobrowolnym datkiem [Geron, 2012].

${ }^{10} \mathrm{~W}$ tym kontekście pojawiają się krytyczne głosy, że ekonomia współpracy to nic nowego, bo współpraca istnieje od zawsze (vide: lumpeksy), jest to tylko udający coś nowego nowy rodzaj biznesu - sharewashing (jako nawiązanie do greenwashing). To dodatkowo dowodzi, jak istotna dla rozwoju EW jest rewolucja cyfrowa. 
zaspokajającymi potrzeby społeczne, przekształcającymi społeczne i międzyludzkie relacje oraz przyczyniającymi się do upodmiotowienia różnych grup interesariuszy. Skoro każdy może sprzedać lub wypożyczyć dobra wcześniej niebrane przez rynek pod uwagę, staje się przedsiębiorcą - bardziej niezależnym, w tym także finansowo.

\section{Ekonomia współpracy — próby klasyfikacji}

Szerokie spektrum EW sprawia, że cały czas toczy się dyskusja, co stanowi istotę tego zjawiska, jak klasyfikować wpisujące się w nie przedsięwzięcia i projekty (kategorie EW) oraz w jakim stopniu dane działanie jest przykładem EW (poziom/zakres współdzielenia).

R. Botsman [2013] wyróżniła w ramach EW cztery ważne obszary, do których autorki przypisały rozwijające się w ich ramach kategorie EW:

- produkcja (dotyczy projektowania, produkowania i dystrybucji dóbr poprzez sieci społecznościowe) - np. kooperatywy spożywcze, RWS (rolnictwo wspierane przez społeczność);

- konsumpcja (cyrkulacja produktów i usług poprzez dzielenie się, wymianę, sprzedaż, wypożyczanie lub nieodpłatne przekazywanie, także użytkowanie współdzielone) - np. coworking (współdzielenie przestrzeni biurowych), carpooling, car sharing, ride sharing, jadłodzielnie, tool sharing, couchsurfing, swapy np. ubraniowe, banki czasu, streaming wideo oraz muzyki;

- finanse (bezpośrednia bankowość pomiędzy ludźmi i społecznościowe modele inwestycji) - np. crowdfounding, pożyczki i ubezpieczenia społecznościowe;

- wiedza (powszechny i darmowy dostęp do wiedzy, otwarta edukacja) np. user-driven innovation czy croudsourcing, bezpłatne oprogramowanie, bookcrossing, skill sharing.

Wydaje się zasadne dodać za OuiShare do tej klasyfikacji jeszcze jeden obszar, czyli:

- otwarte i poziome zarządzanie (obejmujące zmiany w organizacjach, usługach publicznych i zaangażowaniu obywateli) - np. budżety partycypacyjne i inne zaawansowane formy partycypacji oraz kooperatywy [The Collaborative Economy, 2016].

Zmodyfikowana klasyfikacja R. Botsman wskazuje główne rodzaje działalności, w jakich rozwija się EW, skupiając się tym samym na charakterystycznych dla tych działalności kategoriach EW. Generalnie podział ten można uznać za rozłączny.

Inne podejście (branżowe) proponuje J. Owyang, w ramach kolejnych wersji tak zwanego plastra miodu ekonomii współpracy (collaborative economy honey$\mathrm{comb}$ ), pokazujących, jak EW rozprzestrzenia się na coraz to nowe gałęzie i branże (oraz podklasy w ich ramach). Model 1.0 zawierał sześć obszarów (towary, usługi, przestrzeń, żywność, transport, finanse) [Owyang, 2014c], których liczba wzrosła do dwunastu w wersji 2.0 (uwzględniono dodatkowo zdrowie i urodę, korporacje, 


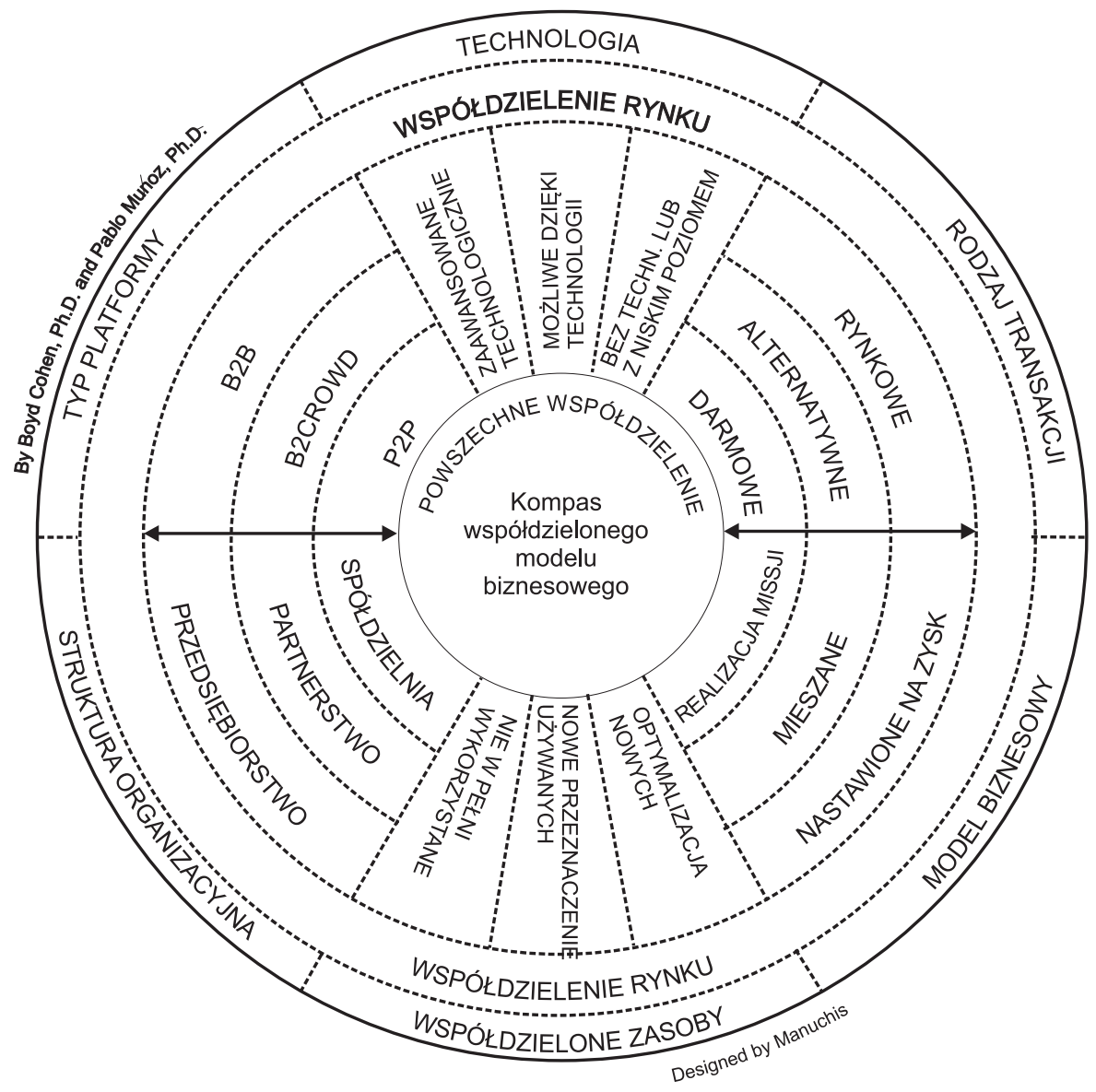

Rys. 2. Kompas współdzielonego modelu biznesowego

Źródło: Cohen, 2016; polska wersja modelu za: Sokołowski et al., 2016.

media, logistykę, usługi komunalne, naukę) [Owyang, 2014d]. W najnowszym modelu 3.0 wyróżniono już szesnaście komórek plastra [Owyang, 2016]. Plaster miodu ilustruje rosnący zasięg branżowy EW, jednak zwiększająca się liczba branż sprawia, że z punktu widzenia wymienionych wcześniej kategorii EW, przyjęty podział nie jest rozłączny. Szczegółowa analiza modelu 3.0 (w tym podanych w nim przykładów firm, z którymi można bliżej się zapoznać dzięki globalnej bazie www.meshing.it, skupiającej firmy ekonomii współpracy z całego świata) potwierdza w gruncie rzeczy wcześniejszy wniosek, że EW rządzi się własnymi zasadami i tradycyjne podziały nie oddają precyzyjnie jej specyfiki.

W tym miejscu warto zaznaczyć, że w pojęciu EW zawiera się ekonomia współdzielenia, która wiąże się z współużytkowaniem i współdzieleniem nie w pełni 
wykorzystywanych zasobów, za opłatą lub nie, bezpośrednio od osób indywidualnych, przy użyciu platform internetowych [Botsman, 2015]. Jest to termin najczęściej używany w odniesieniu do opisu nowego trendu ${ }^{11}$ (nadal często zamiennie z EW) [Armstrong, 2016], ten obszar EW ma bowiem największy wkład w rozwój nowej ekonomii, przez co jest najczęściej dostrzegany i najszerzej analizowany. Wychodząc m.in. z takiego założenia, w 2016 roku Boyd Cohen i Pablo Muñoz zaproponowali kompas współdzielonego modelu biznesowego (Sharing Business Model Compass), w ramach którego wskazali różne kryteria oceny przedsięwzięć ekonomii współdzielenia (technologia, współdzielone zasoby, typ modelu biznesowego, rodzaj transakcji, typ platformy, struktura organizacyjna) oraz występujące w ramach tych kryteriów poziomy (skale) - Rysunek 2. Zbliżanie się do rdzenia kompasu oznacza zwiększanie zakresu współdzielenia w danym przedsięwzięciu [Cohen, 2016].

\section{Ekonomia współpracy — wybrane dobre praktyki}

W Polsce przedsięwzięcia EW nie są jeszcze zbyt rozpowszechnione. Zainteresowanie tym nowym zjawiskiem można obserwować przede wszystkim w sektorze biznesu, gdzie przykłady EW są coraz liczniejsze. To przykłady zarówno nowych modeli biznesowych, bazujących w całości na idei EW, jak i praktyk polegających na włączeniu w istniejący już model biznesowy jakiejś kategorii EW [Stokes et al., 2014: 14]. Wśród przykładów włączenia podejścia EW w prowadzoną działalność biznesową można wymienić m.in.: poszukiwanie pracowników za pomocą Sharehire, angażowanie klientów czy pracowników w ramach user-driven innovation czy poszukiwania nowych innowacji za pomocą crowdsourcing (np. platforma Bank Pomysłów Banku Zachodniego WBK ${ }^{12}$, platforma Imagine Orange ${ }^{13}$ czy program dla pracowników Telekreator Orange Polska). W jednostkach samorządu terytorialnego mamy do czynienia wyłącznie z próbami wykorzystania idei EW na rzecz lepszego funkcjonowania organizacji (vide: budżety obywatelskie), choć być może zmieni się to w przyszłości, szczególnie w miastach, które mają aspiracje, by być smart [Glind, 2013].

Przykłady EW zidentyfikowane w Polsce zostały przedstawione na Rysunku 3. Jedną z prób opisania zjawisk EW w naszym kraju stanowi polska wersja plastra miodu ekonomii współpracy - zob. Rysunek 4.

${ }^{11}$ Wpisanie do wyszukiwarki Google hasła collaborative economy przyniosło 61 mln wyników, podczas gdy shared economy - $182 \mathrm{mln}$ [dostęp: 16.12.2016]. W $2015 \mathrm{r}$. termin sharing economy został wprowadzony do Oxford English Dictionary.

${ }^{12} \mathrm{https} / / /$ bankpomyslow.bzwbk.pl/ [dostęp: 10.01.2017].

${ }_{13} \mathrm{http}: / /$ imagine.orange.com/ [dostęp: 10.01.2017]. 
PRODUKCJA

- Cohabitat

- API dla SMART City (np. BIHAPI Orange)

\section{ŻYWNOŚĆ}

- kooperatywa spożywcza, np. warszawska Dobrze

- RWS, np. Dobrzyń nad Wisłą

- Foodsharing.pl

- Ranozebrano.pl

- Lokalnyrolnik.pl

- My Yummie

- www.shareyourmeal.net

- UberEATS

\section{FINANSE}

- PolakPotrafi.pl

- Trejdoo.com

- Kokos.pl

- Beesfund

- MegaTotal.pl

\section{TRANSPORT}

- WolneAuto.pl

- Beecar.pl

- jadezabiore.pl

- inOneCar.com

- Veturillo

- nextbike.pl

- Iparkomat.com

- Uber

- www.blablacar.pl

- JedenSlad.pl

- www.scroot.pl

- www.traficar.pl

\section{PRACA}

- TakeTask

- Sir Local

- ShareHire

\section{USŁUGI}

- posprzatajmi.pl

\section{ZARZĄDZANIE}

- budżety partycypacyjne (bardzo rozpowszechnione w Polsce, pierwszym miastem, który wprowadził taki instrument był Sopot w 2011 r.)

- NaprawmyTo.pl

Rysunek 3. Przykłady ekonomii współpracy w Polsce

Źródło: opracowanie własne na podstawie: Zgiep, 2016 oraz web research. 


\section{Polish Collaborative Economy Honeycomb Version 2.0}

Collaborative economy to nowe zjawisko społeczne i ekonomiczne, obejmujące zarówno bezpośrednie świadczenie sobie usług przez ludzi, jak również współużytkowanie, współtworzenie, współ kupowanie, itp. Zjawisko bazuje na skłonności ludzi do współpracy, pomagania innym i dzielenia się swoim czasem oraz zasobami, które jest odwzajemniane w różny sposób (materialny i pozamaterialny). Zaciera się granicą pomiędzy jednostką, a przedsiębiorstwem. Ekonomia współpracy rozwija się w dużej mierze dzięki nowym technologiom internetowym oraz mobilnym, które ułatwiają dostęp do produktów i usług zwiększając ich bezpieczeństwo oraz jakość poprzez m.in. system ocen i ubezpieczenie.

\section{Łukasz Zgiep \\ www.zgiep.com}

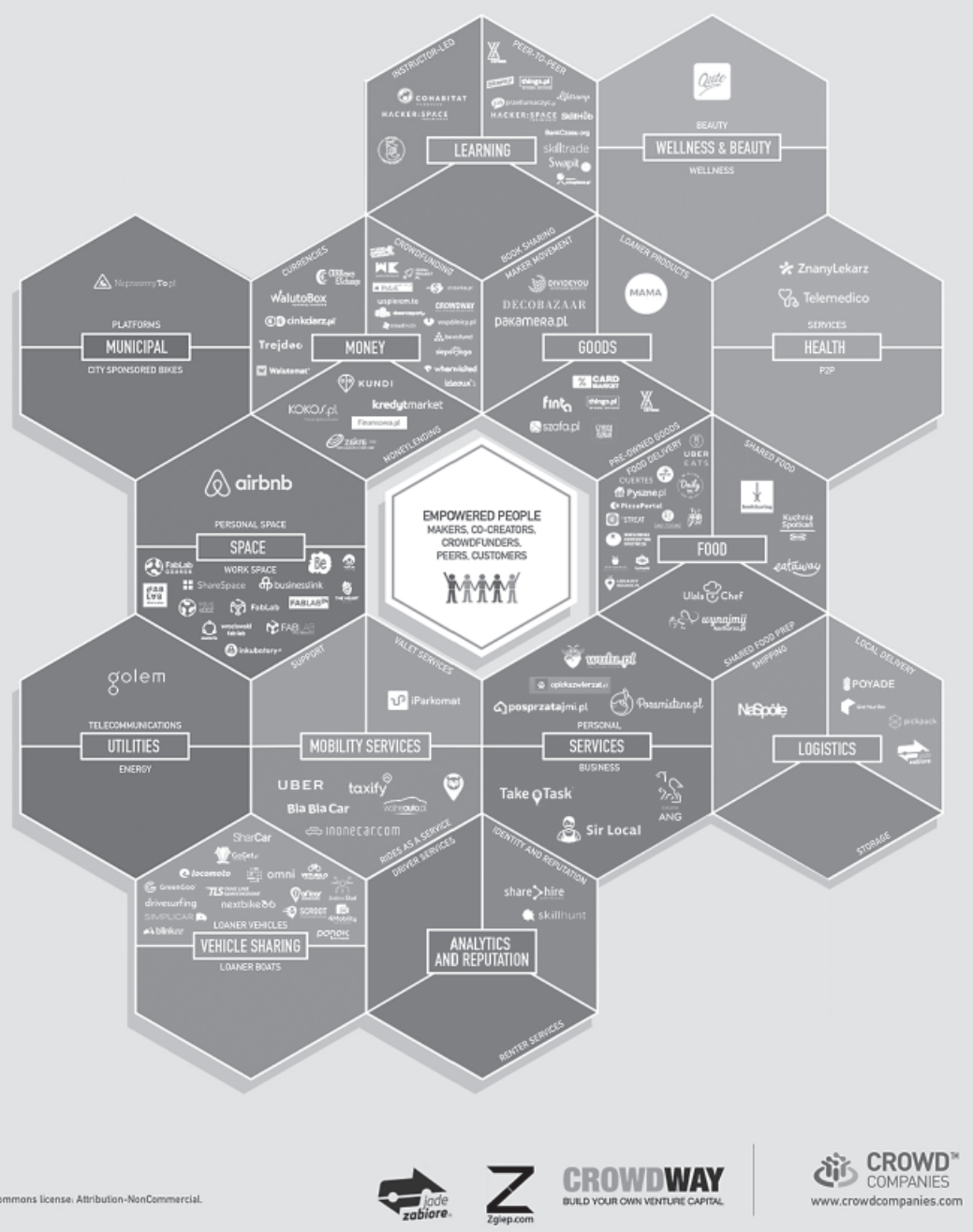

Rysunek 4. Polski plaster miodu ekonomii współpracy

Źródło: Zgiep, 2017. 
Jak wskazano we wcześniejszej części artykułu, w ramach EW największe znaczenie ma ekonomia współdzielenia, przez co pojęcia te są często utożsamiane. Z tego też powodu, przy ocenie wybranych, możliwie różnorodnych przykładów EW występujących w Polsce, bazowano na kryteriach i poziomach (skalach) zaproponowanych w ramach kompasu wspóldzielonego modelu biznesowego (Rysunek 2), zwracając równocześnie uwagę, w jakich punktach analizowane przedsięwzięcia wychodzą poza ten model - zob. Tabela 1. Dla kompleksowego przedstawienia i porównania wybranych przykładów EW uwzględniono w przeprowadzonej analizie dodatkowe kryteria, takie jak:

- rok powstania (co pozwoliło na pokazanie, jak nowe i aktualne jest dane przedsięwzięcie),

- obszar działalności (według zaprezentowanej wcześniej rozszerzonej klasyfikacji R. Botsman),

- współpraca (wychodząc z założenia, że współpraca stanowi istotę EW, analizowano, w jakim stopniu dane przedsięwzięcie oparte jest na współpracy),

- innowacje społeczne (uznając, że wszystkie analizowane przedsięwzięcia są przykładami innowacjispołecznych, oceniano, jakajest ich społecznawartość dodana), a także poszerzono wyszczególnione w ramach kompasu współdzielonego modelu biznesowego kryterium struktura organizacyjna o dwa poziomy (formy) - JST i fundacje.

Analiza Tabeli 1 pozwala przede wszystkim zauważyć, że wszystkie omówione przykłady zafunkcjonowały dzięki ICT oraz współpracy, co potwierdza, że właśnie te dwa elementy są istotą tego typu inicjatyw. Wszystkie przedsięwzięcia można uznać, w mniejszym lub większym stopniu, za innowacje społeczne, co po części wynika z tego, że są one pionierskimi rozwiązaniami na rynku polskim. Najczęściej przedstawione przykłady EW opierają się na optymalizacji (nowych) zasobów, a ich model biznesowy jest mieszany. Każde przedsięwzięcie funkcjonuje w ramach innej struktury organizacyjnej, reprezentuje inny obszar działalności. Najstarsze funkcjonuje od 2007 roku.

Przedsięwzięcia EW bazują na zdecentralizowanych sieciach jednostek i społeczności oraz rynków, muszą zatem osiągnąć pewną krytyczną masę (jak sieci społecznościowe) oraz płynność (jak rynki, nawet lokalne), by stały się bardziej użyteczne [Makkonen, 2015]. Badanie Eurobarometru (2016) pokazało, że 52\% Europejczyków słyszało o platformach ekonomii współpracy, 17\% - korzystało z nich, a wśród tych użytkowników $32 \%$ było także dostarczycielami dóbr i usług. Do głównych korzyści z EW zaliczyli oni: wygodniejszy dostęp do usług (41\% odpowiedzi), tańsze lub nawet darmowe usługi (33\%), możliwość wymiany dóbr i usług zamiast kupowania (25\%) oraz oferowanie nowych lub innych usług (24\%) [Flash Eurobarometer 438. Report..., 2016: 5, 12, 15]. Według badań PwC (2016), $40 \%$ dorosłych Polaków słyszało o platformach, dzięki którym osoby prywatne odpłatnie świadczą usługi, a 26\% aktywnie z nich korzysta. Dla nich głównymi zaletami korzystania z EW jest: korzystna cena (54\% ankietowanych), możliwość poznania ciekawych ludzi (30\%) i wygoda (21\%) [PwC, 2016: 4, 9].

EW nie jest już niszowym zjawiskiem, lecz szybko rosnącym trendem na dużą skalę, angażującym miliony osób prywatnych w liczne przedsięwzięcia, przynoszące 


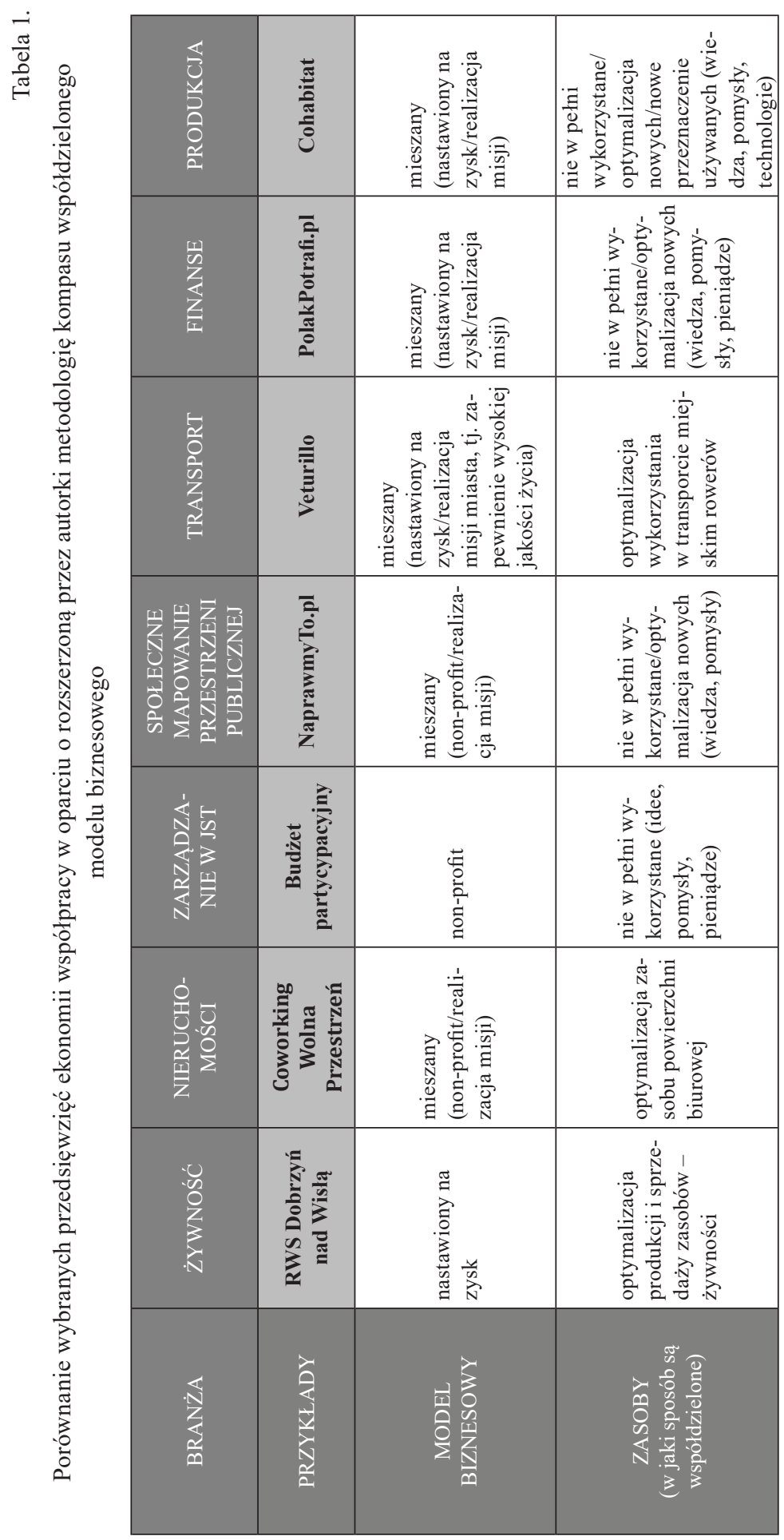




\begin{tabular}{|c|c|c|c|c|c|c|}
\hline 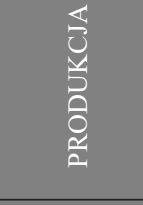 & 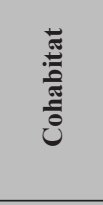 & 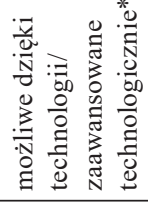 & 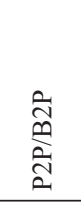 & 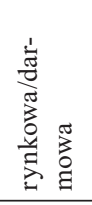 & $\frac{\pi}{\stackrel{\pi}{0}}$ & 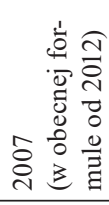 \\
\hline $\begin{array}{l}\frac{1}{\bar{n}} \\
\frac{\pi}{Z} \\
\text { 至 }\end{array}$ & 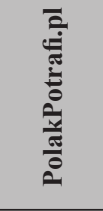 & 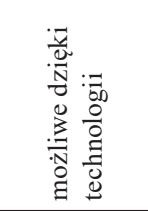 & 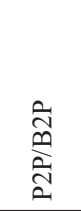 & 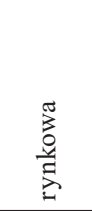 & 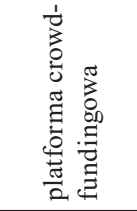 & $\stackrel{\sim}{\vec{\sim}}$ \\
\hline 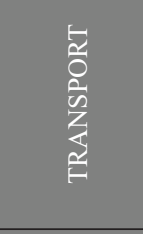 & 产 & 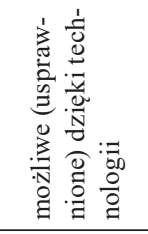 & Фิ & 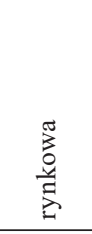 & 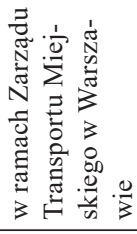 & $\stackrel{\sim}{\stackrel{\sim}{\sim}}$ \\
\hline 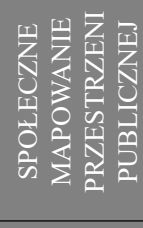 & 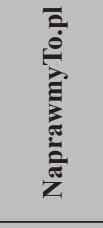 & 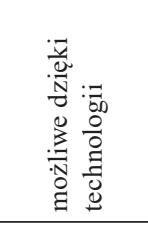 & 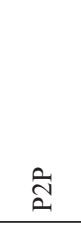 & 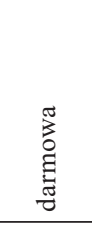 & 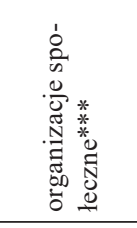 & 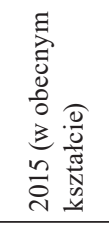 \\
\hline 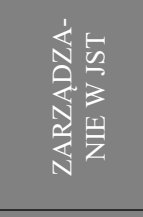 & 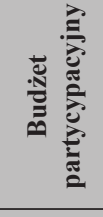 & 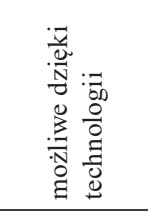 & 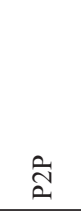 & 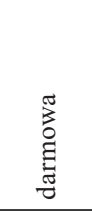 & 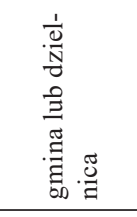 & $\begin{array}{l}\vec{\Xi} \\
i \\
0 \\
0 \\
0 \\
0 \\
0 \\
0 \\
0 \\
3\end{array}$ \\
\hline 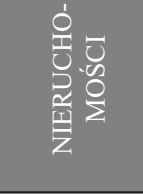 & 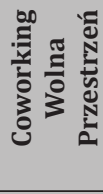 & 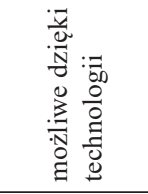 & $\hat{\mathbf{\Lambda}}$ & 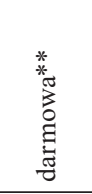 & $\begin{array}{l}\frac{\pi}{0} \\
\stackrel{\pi}{\pi} \\
\Xi \\
\end{array}$ & $\stackrel{\nabla}{\stackrel{D}{*}}$ \\
\hline 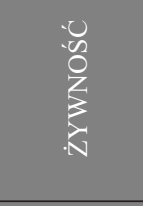 & 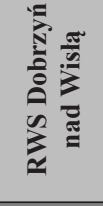 & 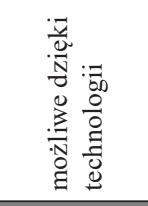 & 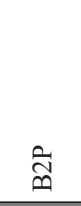 & 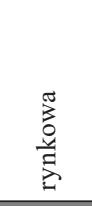 & $\begin{array}{l}0 \\
3 \\
0 \\
\vdots \\
0 \\
0 \\
0 \\
0 \\
0 \\
0 \\
0\end{array}$ & $\stackrel{m}{\stackrel{n}{二}}$ \\
\hline $\begin{array}{l}\text { 尛 } \\
\frac{1}{m}\end{array}$ & 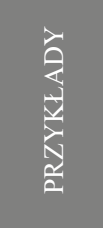 & 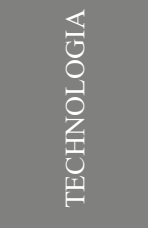 & 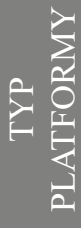 & 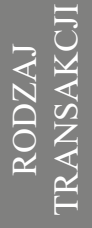 & 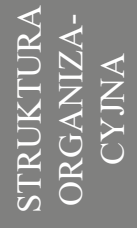 & 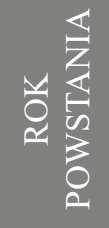 \\
\hline
\end{tabular}




\begin{tabular}{|c|c|c|c|}
\hline 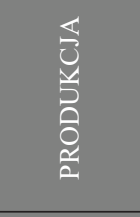 & 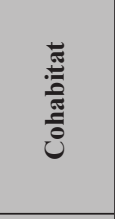 & 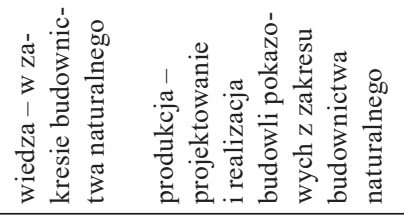 & 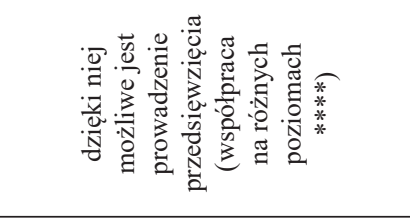 \\
\hline 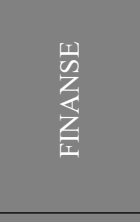 & 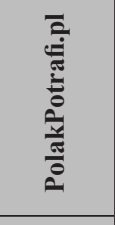 & 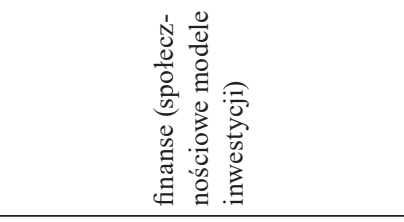 & 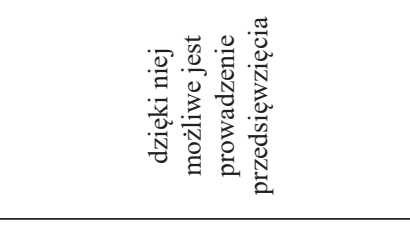 \\
\hline 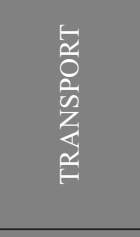 & 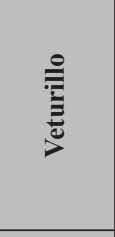 & 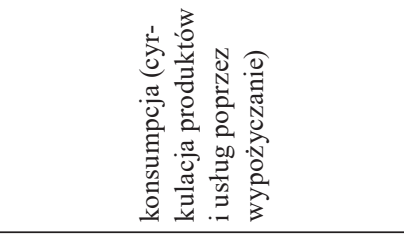 & 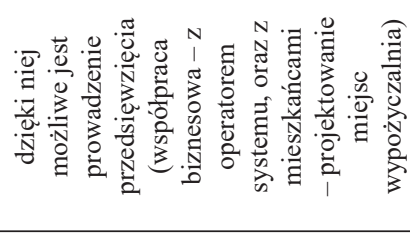 \\
\hline 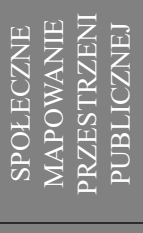 & 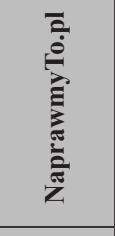 & 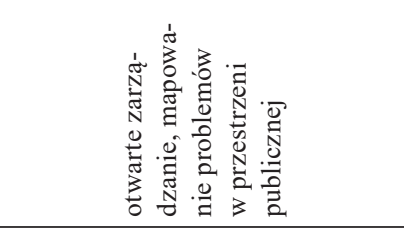 & 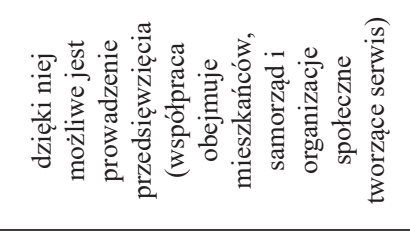 \\
\hline 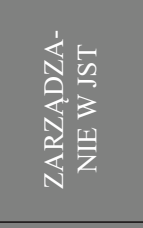 & 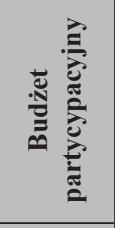 & 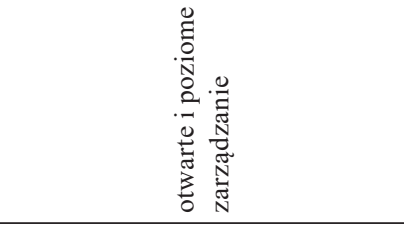 & 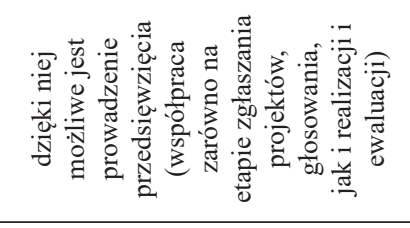 \\
\hline 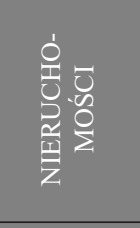 & 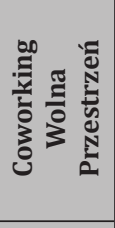 & 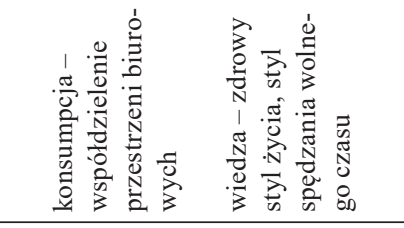 & 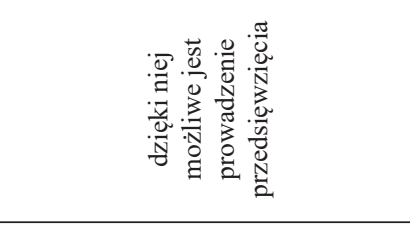 \\
\hline 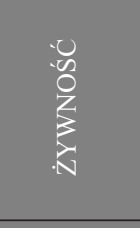 & 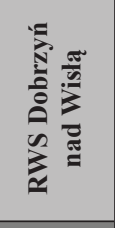 & 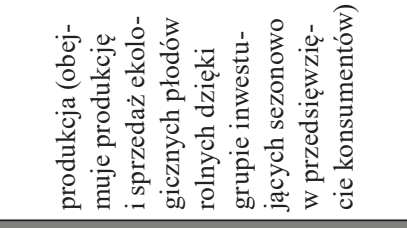 & 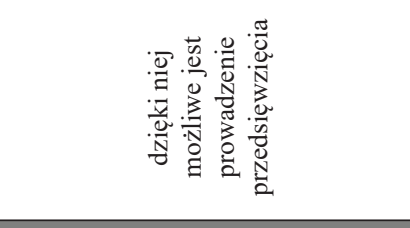 \\
\hline$\frac{\mathbb{N}}{\mathrm{Z}}$ & 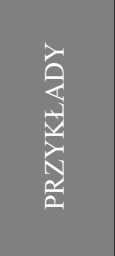 & 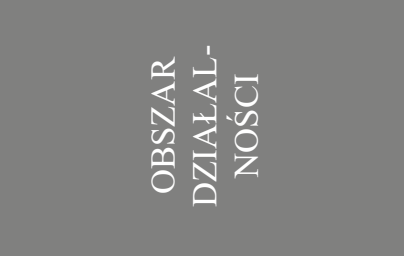 & 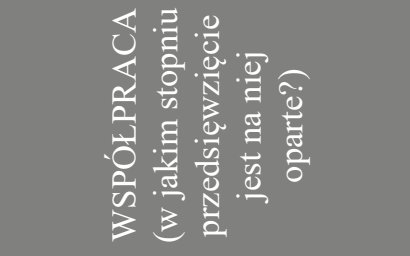 \\
\hline
\end{tabular}




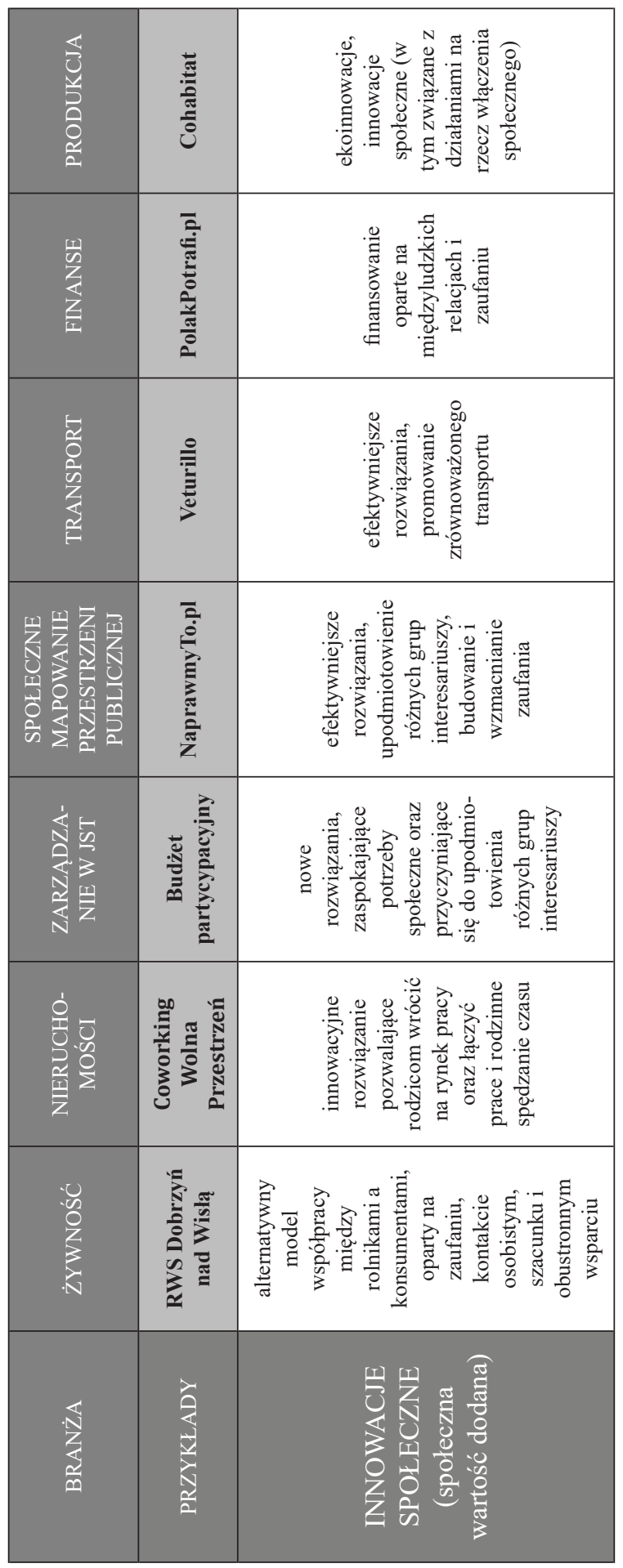

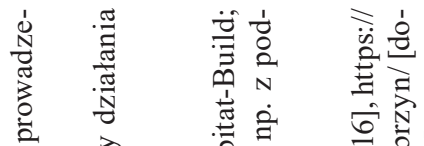

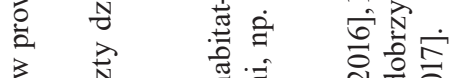

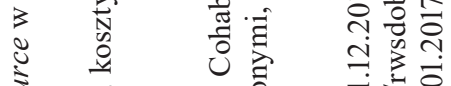

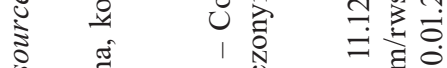

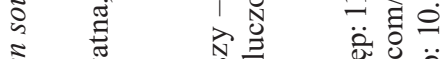

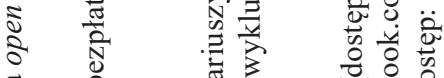

.

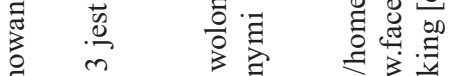

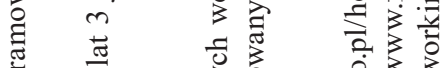

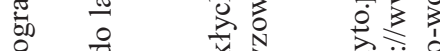

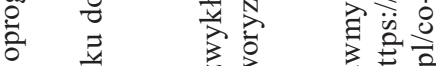

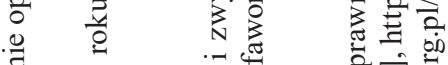

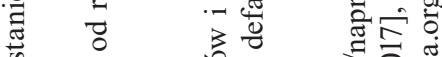

ते

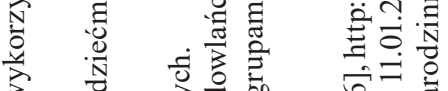

इ टे की

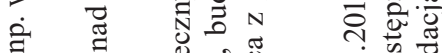

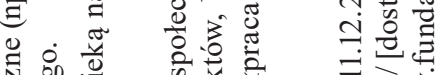

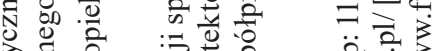

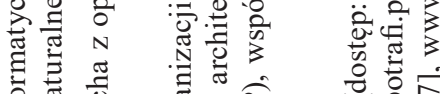

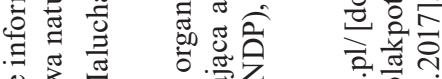

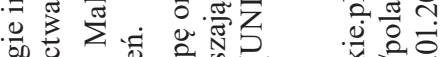

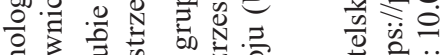

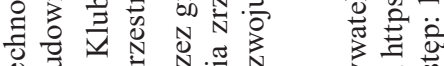

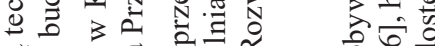

西.

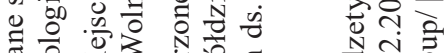

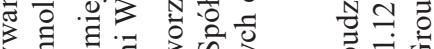

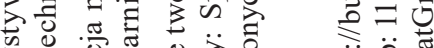

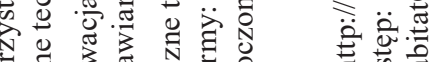

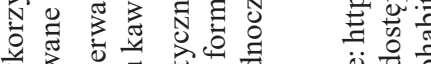

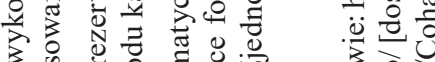

उ兄.

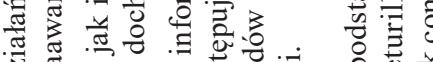

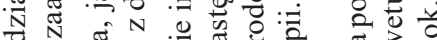

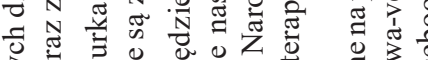

ठ․ㅠ

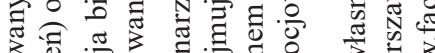

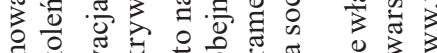

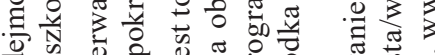

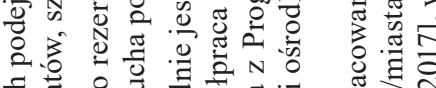

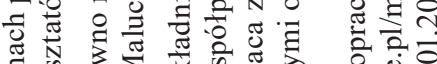

घ

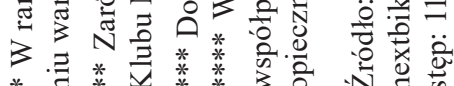


ogromne zyski ${ }^{14}$ i korzyści [Zgiep, 2016; Owyang, 2014a]. EW pobudza bowiem innowacyjność, konkurencyjność i rozwój poprzez umożliwienie pojedynczym osobom świadczenia zupełnie nowych usług, wspieranie nowych, elastycznych form zatrudnienia i nowych źródeł dochodu, prowadząc do rozszerzenia asortymentu, poprawy jego jakości i obniżenia cen, a także bardziej efektywnego wykorzystania zasobów. EW przyczynia się także do budowania kapitału społecznego i społeczeństwa obywatelskiego, prowadząc do upodmiotowienia użytkowników, wzmacniając relacje międzyludzkie, zaufanie ${ }^{15}$. EW pozwala bowiem także na wdrażanie otwartego i poziomego zarządzania, stanowiącego podstawę zarządzania partycypacyjnego, w którym podkreśla się sieciowy i partnerski charakter relacji w procesie współzarządzania [Noworól, 2013: 22-23].

Równocześnie należy zauważyć, że przedsięwzięcia EW są wyzwaniem dla funkcjonujących podmiotów gospodarczych, podważając dotychczasowe modele rynkowe, oraz dla regulatorów, rodząc z jednej strony obawy o kwestie związane z zapewnieniem bezpieczeństwa konsumenckiego i publicznego, z drugiej - ryzyko przeregulowania i karania podejmujących takie aktywności zamiast ich wspierania [Koopman et al., 2014; PwC, 2016]. EW stanowi także wyzwanie dla JST, bo wymusza inne, nowe kanały komunikacji i współpracy.

\section{Podsumowanie}

Termin ekonomia współpracy narodził się dopiero w 2009 roku w toku dyskusji nad pojawiającymi się różnymi określeniami i próbami zdefiniowania tego nowego fenomenu, podejmowanymi przez różnych badaczy (m.in. D. Tapscotta i A.D. Williamsa, J. Rifkina, a przede wszystkim J. Owyanga i R. Botsman).

Chociaż siłą napędową EW są Millenialsi (bo EW jest nie tylko zgodna $\mathrm{z}$ ich naturą, lecz także odpowiada na ich oczekiwania), to trend ten dotyczy wszystkich grup pokoleniowych. EW jest nie tyle niszowym zjawiskiem społecznym, ile coraz bardziej mainstreamowym trendem wynikającym z rewolucji cyfrowej.

Istotą EW są rozproszone sieci powiązanych z sobą jednostek i społeczności, czyli współpraca (której fundamentem jest zaufanie), ale stymulowana i wspomagana narzędziami ICT. Wśród głównych cech przedsięwzięcia EW należy wymienić: funkcjonowanie dzięki ICT; łączenie rozproszonych sieci osób i aktywów; wykorzystywanie marnotrawionego potencjału zasobów; zachęcanie do interakcji i otwartości oraz wspieranie włączenia i wspólnoty. Choć termin ekonomia współdzielenia używany jest często zamiennie z EW, to jedynie zawiera

${ }^{14}$ W 2014 r. PwC oszacowało, że globalny przychód z ekonomii współdzielenia w pięciu kluczowych sektorach: usługi finansowe, transport, hotelarstwo i turystyka, usługi profesjonalne, wyniesie 335 mld dolarów do 2025 r. [PwC, 2014].

${ }^{15}$ Komunikat Komisji do Parlamentu Europejskiego, Rady, Europejskiego Komitetu Ekonomiczno-Społecznego i Komitetu Regionów, Europejski program na rzecz gospodarki dzielenia się, Bruksela, dnia 2.6.2016 r., $\operatorname{COM(2016)~} 356$ final, s. 2. 
on się w pojęciu EW, ponieważ wiąże się z współużytkowaniem i współdzieleniem nie w pełni wykorzystywanych zasobów, za opłatą lub nie, bezpośrednio od osób indywidualnych, przy użyciu platform internetowych. Z pewnością jednak ten obszar EW ma największy wkład w rozwój nowej ekonomii, przez co jest najczęściej dostrzegany.

Podejmowane próby klasyfikacji EW pokazują, że EW rządzi się własnymi zasadami i tradycyjne podziały nie oddają precyzyjnie jej specyfiki - choć podział na charakterystyczne kategorie EW występujące w ramach głównych rodzajów działalności można uznać za rozłączny, to podział branżowy (w ramach plastra miodu współpracy), pokazujący rosnący zakres przedsięwzięć EW - już nie.

Ocena wybranych polskich dobrych przykładów EW, bazująca na kompasie współdzielonego modelu biznesowego B. Cohena i P. Muñoza, pozwoliła stwierdzić, że zjawisko to w Polsce jest nowe, a podejmowane przedsięwzięcia EW bardzo różnorodne. Wszystkie jednak przedsięwzięcia bazują na ICT i współpracy - fundamentach tej nowej idei.

Na koniec trzeba podkreślić, że coraz więcej organizacji (zarówno biznesowych, jak i niebiznesowych) szuka sposobów wykorzystania tych nowych możliwości reagując na ewoluujące potrzeby interesariuszy, dopasowują swoje modele i formy działania do nowych zjawisk, chcąc pokazać, że oni również są zaangażowani w EW. Budzić to może czasami wątpliwości, czy nie jest to aby tylko kolejna forma kapitalizmu, sposób budowania wizerunku i reputacji, a nie - współpracy i zaufania, tworzenia nowej wartości, lepszej alternatywy dla wszystkich interesariuszy. Jednak warto pamiętać, że bardzo często przedsięwzięcia EW są zarazem innowacjami społecznymi, prowadzącymi do systemowej zmiany społecznej i przyczyniającymi się do upodmiotowienia i zaangażowania beneficjentów, których dotyczą. Tym samym wzrost popularności EW przyczynia się do wdrażania zarządzania partycypacyjnego oraz rozwoju idei smart cities.

\section{Bibliografia}

Armstrong P. (2016), Why You Need To Know More About The Collaborative Economy And How It Will Affect You, „Forbes”, November 1.

Botsman R. (2013), The Sharing Economy Lacks A Shared Definition, www.fastcoexist. com/3022028/the-sharing-economy-lacks-a-shared-definition [dostęp: 07.01.2017].

Botsman R. (2015), Defining The Sharing Economy: What Is Collaborative Consumption And What Isn't?, www.fastcoexist.com/3046119/defining-the-sharing-economy-what-is-collaborative-consumption-and-what-isnt [dostęp: 10.12.2016].

Cohen B. (2016), Making Sense Of The Many Business Models In The Sharing Economy, www.fastcoexist.com/3058203/making-sense-of-the-many-business-models-in-the-sharing-economy [dostęp: 11.12.2016].

Conley Ch. (2017), Rozpoczątem prace $w$ Airbnb, majac 52 lata. Oto czego dowiedziałem się o wieku, mądrości $i$ branży technologicznej, www.hbrp.pl/b/ 
rozpoczalem-prace-w-airbnb-majac-52-lata-oto-czego-dowiedzialem-sie-o-wieku-madrosci-i-branzy-technologicznej/P1BgI7ZBf8 [dostęp: 21.08.2017].

Eckhardt G.M., Bardhi F. (2015), The Sharing Economy Isn't About Sharing at All, „Harvard Business Review", January 28.

Flash Eurobarometer 438. Report. The use of collaborative platforms, European Commission, (June 2016), http://ec.europa.eu/commfrontoffice/publicopinion/index.cfm/ResultDoc/download/DocumentKy/72885 [dostęp: 16.12.2016].

Geiger A. (2017), Millennials are the most likely generation of Americans to use public libraries, www.pewresearch.org/fact-tank/2017/06/21/millennials-are-the-most-likely-generation-of-americans-to-use-public-libraries/ [dostęp: 21.08.2017].

Geron T. (2012), Will Ride-Sharing Apps Replace Car Ownership?, „Forbes”, July 9.

Geron T. (2013), Airbnb And The Unstoppable Rise Of The Share Economy, „Forbes”, February 11 .

Glind van de P. (2013), Amsterdam: Europe's First Shareable City?, www.collaborativeconsumption.com/2013/11/27/amsterdam-europes-first-shareable-city/, 27.11. [dostęp: 12.12.2016].

Grossman L. (2006), You - Yes, You-Are TIME's Person of the Year, „Time”, December 25. Komunikat Komisji do Parlamentu Europejskiego, Rady, Europejskiego Komitetu Ekonomiczno-Społecznego i Komitetu Regionów, Europejski program na rzecz gospodarki dzielenia się, Bruksela, dnia 2.6.2016 r., COM(2016) 356 final, www.ipex.eu/IPEXL-WEB/dossier/document/COM20160356.do [dostęp: 12.12.2016].

Koopman Ch. et al. (2014), The Sharing Economy and Consumer Protection Regulation: The Case for Policy Change, Mervatus Center, Arlington, December, www.mercatus.org/system/files/Koopman-Sharing-Economy.pdf [dostęp: 17.12.2016].

Makkonen J. (2015), Why He Collaborative Economy Is Not Like Social Media, http://magazine.ouishare.net/2015/09/why-the-collaborative-economy-is-not-like-social-media/ [dostęp: 11.12.2016].

Noworól A. (2013), Ku nowemu paradygmatowi planowania terytorialnego, Wydawnictwo CeDeWu, Warszawa.

Owyang J. (2014a), Report: Sharing is the New Buying, Winning in the Collaborative Economy, www.web-strategist.com/blog/2014/03/03/report-sharing-is-the-new-buying-winning-in-the-collaborative-economy/ [dostęp: 15.12.2016].

Owyang J. (2014b), It's Just the Economy, www.web-strategist.com/blog/2014/01/24/its-justthe-economy/ [dostęp: 10.12.2016].

Owyang J. (2014c), Framework: Collaborative Economy Honeycomb, www.web-strategist. com/blog/2014/05/05/framework-collaborative-economy-honeycomb-osfest14/ [dostęp: 11.12.2016].

Owyang J. (2014d), Collaborative Economy Honeycomb 2 - Watch it Grow, www.web-strategist.com/blog/2014/12/07/collaborative-economy-honeycomb-2-watch-it-grow/ [dostęp: 10.12.2016].

Owyang J. (2015), The Collaborative Economy Defined, www.web-strategist.com/ blog/2015/08/27/the-collaborative-economy-defined/ [dostęp: 08.12.2016].

Owyang J. (2016), Honeycomb 3.0: The Collaborative Economy Market Expansion, www. web-strategist.com/blog/2016/03/10/honeycomb-3-0-the-collaborative-economy-marketexpansion-sxsw/ [dostęp: 10.12.2016]. 
PwC (2014), The Sharing Economy - Sizing the Revenue Opportunity, www.pwc.co.uk/issues/megatrends/collisions/sharingeconomy/the-sharing-economy-sizing-the-revenueopportunity.html [dostęp: 14.12.2016].

PwC (2016), (Wspót)dziel i rządź! Prawno-podatkowe aspekty ekonomii współdzielenia w Polsce, www.pwc.pl/pl/pdf/ekonomia-wspoldzielenia-raport-2-pwc.pdf [dostęp: 17.12.2016].

Rifkin J. (2000), The Age of Access: The New Culture of Hyper Capitalism Where All of Life Is A Paid-For Experience, Tarcher, New York.

Rifkin J. (2014), The Zero Marginal Cost Society: The Internet of Things, the Collaborative Commons, and the Eclipse of Capitalism, Palgrave Macmillan, New York.

Sokołowski D., Starzyński S., Rok B., Zgiep Ł. (2016), Raport. Ekonomia wspótpracy w Polsce 2016, Społeczność Ekonomia Współpracy, http://ekonomiawspolpracy.pl/ [dostęp: 09.04.2018].

Stokes K. et al. (2014), Making Sense of the UK Collaborative Economy, Nesta, Collaborative Lab, wrzesień, www.collaboriamo.org/media/2014/10/making_sense_of_the_uk_collaborative_economy_14.pdf [dostęp: 10.12.2016].

Tapscott D., Williams A.D. (2006), Wikinomics. How Mass Collaboration Changes Everything, Penguin Group, New York.

The Collaborative Economy (2016), http://ouishare.net/en/about/collaborative_economy [dostęp: 12.12.2016].

The rise of the sharing economy (2013), „The Economist”, March 9, www.economist. com/news/leaders/21573104-internet-everything-hire-rise-sharing-economy [dostęp: 10.12.2016].

Zgiep Ł. (2016), Korzyści i obszary ekonomii wspótpracy w Polsce i na świecie, http:// zgiep.com/korzysci-i-obszary-ekonomii-wspolpracy-w-polsce-i-na-swiecie/ [dostęp: 16.12.2016].

Zgiep Ł. (2017) Collaborative Economy HoneyComb 2.0 - premiera!, http://zgiep.com/collaborative-economy-honeycomb-2-0/ [dostęp: 17.12.2017]. 